\title{
UJI COBA TEKNOLOGI BIOFILM KONSORSIUM BAKTERI PADA REAKTOR SEMIANAEROB-AEROB UNTUK PENGOLAHAN AIR LIMBAH DI INDUSTRI PENCELUPAN TEKSTIL SKALA RUMAH TANGGA
}

\author{
Dewa Ketut Sastrawidana ${ }^{1}$ dan I Nyoman Sukarta ${ }^{2}$ \\ ${ }^{1} J u r u s a n$ Pendidikan Kimia Fakultas matematika dan IImu Pengetahuan Alam \\ 2Jurusan Analis Kimia Fakultas matematika dan IImu Pengetahuan Alam \\ Universitas Pendidikan Ganesha \\ Singaraja, Indonesia \\ Email: idewasastra@yahoo.com
}

\begin{abstract}
Abstrak
Penelitian ini bertujuan untuk menganalisis efektifitas teknologi biofilm konsorsium bakteri pada reaktor semianaerob-aerob ntuk mengolah air limbah pencelupan tekstil. Bakteri pada reaktor semianaerob terdiri dari Aeromonas sp. Pseudomonas sp, dan Flavobacterium sp. sedangkan pada reaktor aerob terdiri dari Vibrio sp. Plesiomonas sp. dan Enterobacter sp. Perombakan proses pertumbuhan terlekat diawali dengan menumbuhkan konsorsium bakteri pada masing-masing reaktor selama 10 hari menggunakan pada batu vulkanik merah sebagai media pelekatan bakteri. Setelah terbentuk biofilm,selanjutnya digunakan untuk merombak limbah denagn waktu tinggal limbah 2 hari. Hasil penelitian menunjukkan teknologi biofilm cukup efektif diaplikasikan pada skala lapang menghasilkan efisiensi perombakan TSS, BOD dan COD secara berturut-turut sebesar $84,7 \%$; $80,56 \%$ dan $90,40 \%$. Uji toksisitas air limbah tekstil menggunakan ikan nila dengan waktu paparan 3 hari menunjukkan bahwa air limbah tekstil sebelum diolah berkatagori toksik ringan dengan nilai $\mathrm{EC}_{50}$ adalah $88,80 \%$ sedangkan setelah diolah dalam reaktor biofilm konsorsium bakteri sistem anaerob-aerob selama 2 hari menjadi katagori tidak toksik dengan nilai $\mathrm{EC}_{50}$ sebesar $101,64 \%$. Dengan demikian, pengolahan limbah tektil dengan sistem kombinasi anaerobaerob menghasilkan kualitas limbah dengan kriteria sudah memenuhi baku mutu untuk dibuang ke lingkungan.
\end{abstract}

Kata-kata kunci: Air limbah tekstil, batu vulkanik, biofilm, semianaerob-aerob,

\begin{abstract}
This study focused on biodegradation of textile wastewater by bacteria consortia which are isolated from sludge of textile wastewater treatment plant. Biodegradation process was carried out in anaerobic-aerobic reactors system Bacteria consortia in semianaerobic reactor consist of Aeromonas sp. Pseudomonas sp, and Flavobacterium sp. while in aerobic reactor consist of Vibrio sp. Plesiomonas sp. dan Enterobacter sp. In attached-growth process, bacteria consortia were attached on red volcanic stone for 10 days to form biofilm then used to treat the wastewater. The system was operated for two days.The result showed biofilm technology is potential for treatment of textile wastewater. This technology is effective to decrease TSS, BOD dan COD up to $84,7 \% ; 80,56 \%$ dan $90,40 \%$, repectively and the result process become lesstoxic.
\end{abstract}

Keywords: Textile wastewater, volcanic stone, biofilm, semianaerobic-aerobic 


\section{PENDAHULUAN}

Karakteristik limbah cair industri tekstil sangat komplek dan hampir $70 \%$ zat warna yang digunakan adalah zat warna sintetik azo yang bersifat recalsitran (Blackburn dan Burkinshaw, 2002). Air limbah tersebut bila dibuang secara langsung ke lingkungan tanpa diolah terlebih dahulu maka dipastikan dapat menurunkan nilai estetika lingkungan dan mengancam kelestarian ekosistem akuatik. Kandungan zat warna dalam air sebesar $1 \mathrm{mg} / \mathrm{L}$ sudah menyebabkan air tampak berwarna, sementara kandungan zat warna pada limbah tekstil umumnya berkisar antara $20-200 \mathrm{mg} / \mathrm{L}$ sehingga dapat menyebabkan terjadinya perubahan yang ekstrim pada beberapa parameter kualitas air (Pandey et al. 2007).

Dalam rangka pengendalian pencemaran air oleh limbah industri, Pemerintah Republik Indonesia telah mengeluarkan KepMen LH No. 51/MENLH/10/1995 tentang baku mutu limbah cair bagi kegiatan industri. Perundang-undangan tersebut pada intinya mewajibkan setiap usaha dan atau kegiatan melakukan pengolahan limbah sampai memenuhi persyaratan baku mutu air limbah sebelum dibuang ke lingkungan. Untuk itu, penyediaan teknologi pengolahan air limbah tekstil yang efektif, efisien dan ramah lingkungan sangat penting untuk dilakukan. Salah satu teknologi potensial dikembangkan adalah menggunakan bakteri lokal.

Menurut Yoo (2000), perombakan zat warna azo menggunakan bakteri pada dasarnya merupakan reaksi reduksi-oksidasi (redoks) yang dikatalisis oleh enzim. Bakteri memerlukan kosubstrat berupa senyawa karbon organik seperti glukosa untuk mempercepat proses perombakan zat warna azo. Glukosa dalam sistem biologi mengalami proses glikolisis dengan bantuan enzim dehidrogenase menghasilkan koenzim nikotinamida adenin dinukleotida (NADH). Glikolisis mengubah molekul glukosa menjadi dua molekul piruvat yang kemudian diubah menjadi asetil koenzim A yang siap memasuki siklus asam sitrat. Pada proses glikolisis 1 molekul glukosa dihasilkan 2 molekul NADH sedangkan pada siklus asam sitrat dihasilkan tiga molekul $\mathrm{NADH}$ dan satu molekul FADH $\mathrm{F}_{2}$. NADH dan flavin adenin dinukleotida (FADH) merupakan koenzim yang bertindak sebagai pembawa elektron. Koenzim-koenzim ini berperan penting dalam proses perombakan zat warna azo. Peranan NADH pada perombakan zat warna azo dijelaskan melalui hipotesis mekanisme perombakan azo secara biologi yaitu perombakan dengan melibatkan enzim secara langsung (direct enzymatic) yang dilaporkan oleh Wuhrman (1980) Koenzim NADH yang dihasilkan dari proses glikolisis glukosa mentransfer elektron ke zat warna azo yang dikatalisis oleh enzim azoreductase. Koenzim NADH mengalami reaksi oksidasi sedangkan zat warna azo mengalami reduksi menghasilkan senyawa amina aromatik yang tidak berwarna. Selanjutnya, tahap perombakan aerob, amina aromatik diuraikan lebih lanjut menghasilkan produk yang tidak toksik. Perombakan zat warna azo oleh bakteri Pseudomonas KF46 yang dikatalisis oleh enzim azoreductase dengan bantuan glukosa sebagai kosubstrat disajikan pada Gambar 1.

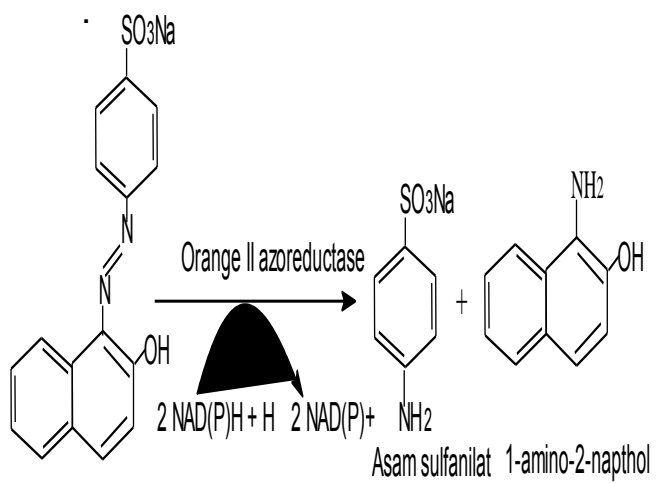

Gambar 1. Perombakan orange II dikatalisis enzim orange II azoreductase.

Jurnal Sains dan Teknologi|194 
Beberapa bakteri seperti Aeromonas sp., Proteus mirabilis, Pseudomonas pseudomallei dan Pseudo luteola telah banyak dikembangkan untuk merombak zat warna azo dengan menggunakan gula sebagai sumber karbon (Chen et al. 1999). Beberapa bakteri anaerob fakultatif seperti Aeromonas sp., Pseudomonas sp., dan Flavobacterium sp. serta bakteri aerob yaitu Plesiomonas sp., dan Vibrio sp. mempunyai aktivitas perombakan terhadap remazol yellow, remazol red, dan remazol blue dengan efisiensi perombakan 91,16-95,17\% selama 5 hari inkubasi(Sastrawidana, 2009). Namun, kelemahan mendasar penggunaan sel bebas ini adalah penambahan kultul bakteri disetiap perombakan limbah sehingga memerlukan stok kultur yang banyak.

Salah satu langkah strategis untuk mengoptimalisasi penggunaan bakteri dalam pengolahan air limbah adalah dengan mengamobilkannya pada padatan pendukung sehingga membentuk biofilm. Biofilm merupakan pertumbuhan mikroorgansime secara terstruktur pada permukaan padatan sehingga membentuk lapisan tipis (Prakas, 2003). Pembentukan biofilm bakteri melalui 3 tahapan proses, yaitu tahap pelekatan bakteri pada permukaan padatan (attachment), kolonisasi, dan tahap pertumbuhan biofilm Proses pembentukan biofilm bakteri (Prakash et al. 2003)

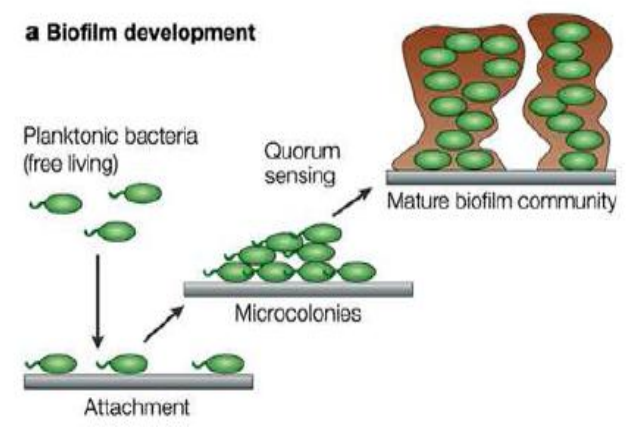

Gambar 2. Prose pembentukan biofilm
Pada tahap pelekatan, bakteri mendekati permukaan melalui gaya elektrostatik maupun gaya fisika. Pada umumnya, ketersediaan nutrisi, suhu air dan laju alir cairan yang memadai serta karakteristik bakteri seperti adanya flagela dan permukaan sel yang terasosiasi dengan poplisakarida atau protein mempercepatan proses pelekatan. telah, bakteri berasosiasi satu sama lainnya membentuk mikrokoloni. Beberapa dari sel bakteri terikat secara permanen pada permukaan material melalui pembentukan Extraselular polymeric substance (EPS) terdiri dari sejumlah besar protein, polisakarida, asam nukleat dan fosfolipid. EPS berfungsi sebagai penghubung antar permukaan sel dan menjadi inisiasi pada pembentukan biofilm. Terbentuknya biofilm sebagai strategi bagi mikroorganisme untuk mempertahankan populasinya karena adanya EPS mencegah difusi senyawa-senyawa toksik yang membahayakan serta mengatur pertumbuhan sel. Teknologi biofilm banyak digunakan untuk produksi etanol menggunakan jamur Saccharomyces cerevisiae, produksi butanol dengan Clostridium acetobutylicum. Bahan pengamobil yang banyak digunakan adalah Ca-alginat, pecahan keramik serta sponge (Qureshi et al. 2005).

Nilai strategis penggunaan biofilm bakteri lokal untuk mengolah limbah tekstil adalah (1) Bakteri lebih resisten terhadap perubahan lingkungan yang ekstrim, (b) Lebih efisien nutrisi, (c) Washout bakteri dapat diminimalkan dan (d) Reaktor dapat digunakan secara berulang sehingga low cost dan dapat digunakan secara berkelanjutan.

Sastrawidana dan Sukarta (2010) melakukan kajian pembentukan biofilm konsorsium bakteri lokal pada reaktor anaerob-aerob menggunakan batu vulkanik sebagai bahan pengamobil. Konsorsium bakteri lokal yang diamobilkan pada batu vulkanik terdiri dari Pseudomonas sp., 
Aeromonas sp., dan Flavobacterium sp. Hasil perhitungan menggunakan metode total plate count menunjukkan jumlah koloni bakteri teramobil sebesar 20,51 $\times 10^{9}$ cfu/gram batu vulkanik. Menurut Cutright (2001), jumlah bakteri yang dianggap memadai digunakan untuk merombak limbah adalah sebesar $10^{4}$ sampai $10^{8} \mathrm{cfu}$ per liter limbah. Dengan demikian, batu vulkanik sangat baik digunakan sebagai bahan pengamobil bakteri.

\section{METODE \\ Mikroorganisme}

Bakteri yang digunakan mengolah air limbah tekstil diisolasi dari lumpur limbah tekstil. Sistem pengolahan limbah yang digunakan adalah semi anaerob-aerob. Konsorsium bakteri pada bak semi anaerob terdiri dari Aeromonas sp., Pseudomonas $\mathrm{sp}$. dan Flavobacterium sp. sedangkan pada bak pengolah aerob terdiri dari Plesiomonas sp., Vibrio sp., dan Enterobacter sp. Konsorsium bakteri pada reaktor semi anaerob dan aerob dilekatkan pada batu vulkanik merah yang diambil dari Desa Tajun Kecamatan Kubutambahan Kabupaten Buleleng.

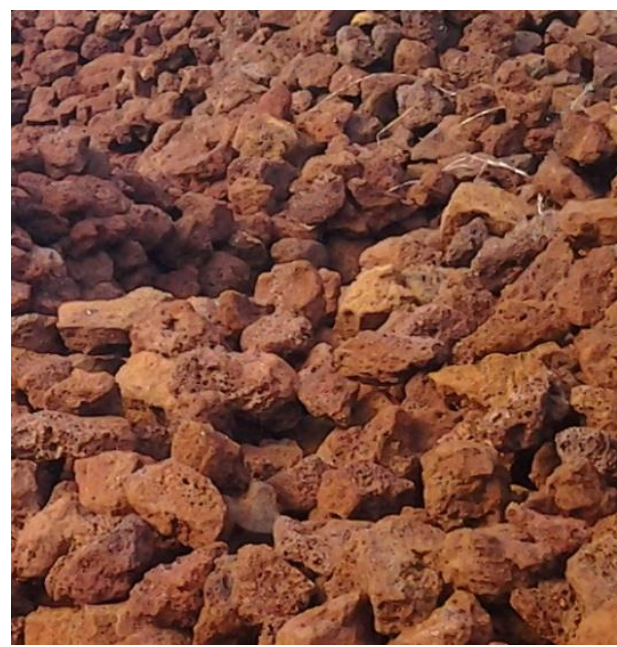

Gambar 3, Batu vulkanik merah asal Desa Tajun.

\section{Perancangan Bioreaktor}

Reaktor semianaerob-aerob terdiri dari 3 bak, yaitu bak pengisi, bak pengolah semianaerob dan bak pengolah aerob. Masing-masing unit bak tersebut mempunyai dimensi panjang $x$ lebar $x$ tinggi adalah 1,5 m x1,5 m x 2 m. Batu vulkanik merah yang digunakan sebagai bahan pengamobil konsorsium bakteri disusun menyerupai saran tawon. Susun bahan pengamobil terdiri atas 3 lapis pada arah vertikal

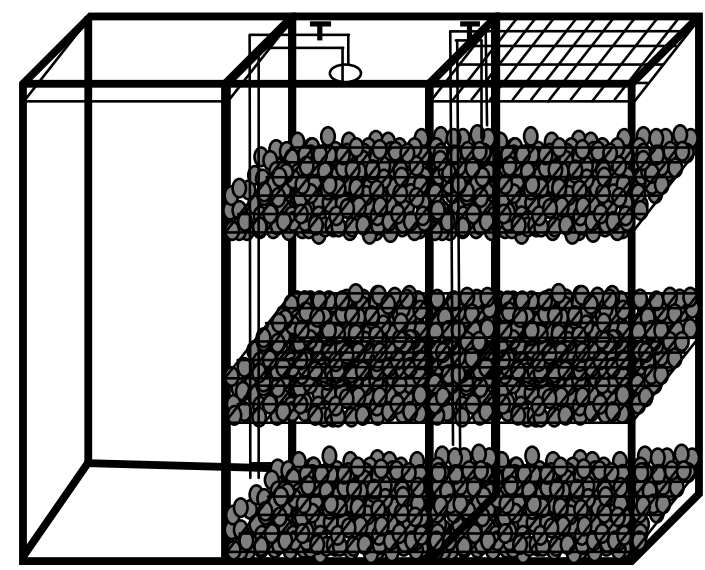

Gambar 3. Reaktor semianaerob-aerob Pembentukan Biofilm Bakteri Pada Batu Vulkanik

Batu vulkanik merah dihancurkan sedemikian rupa untuk memperoleh ukuran dengan diameter kira-kira $25 \mathrm{~cm}$. Proses amobilisasi bakteri pada batu vulkanik mengikuti metode yang telah dilakukan Castilla et al. (2003), yaitu masing-masing sebanyak $100 \mathrm{~L}$ kultur bakteri ditumbuhkan dalam bak pengolah anaerob-aerob, selanjutnya ditambahkan media tumbuh dan dibiarkan selama 10 hari. Untuk pembentukan biofilm pada bak pengolah aerob dilakukan resirkulasi udara dengan cara mengaerasi limbah dengan aerator. Setelah waktu tinggal 10 har, air pada bak pengolah semi anaerob dan bak pengolah aerob di dilairkan keluar dengan 
menggunakan pompa untuk mengeluarkan bakteri yang tidak terlekat pada batu vulkanik merah. Jumlah nutrisi yang ditambahkan pada pembentukan biofilm adalah adalah 1 liter per 250 liter limbah. Komposisi media tumbuh untuk skala lapang berupa pupuk $\mathrm{N}, \mathrm{P}$ dan $\mathrm{K}$ disertai dengan penambahan gula sebagai sumber karbon dan kosubstrat dalam proses perombakan air limbah tekstil

\section{Perombakan Limbah Tekstil Dalam Bak Pengolah}

Air limbah tekstil skala rumah tangga ditempatkan pada bak pengisi dan diatur pHnya menjadi 6-8. Air limbah selanjutnya ditambahkan $1000 \mathrm{~mL}$ media cair dan 500 gram gula. Limbah pada bak pengisi dialirkan ke bak pengolah semi anaerob dengan menggunakan bantuan pompa air.

Proses perombakan pada bak pengolah semi anaerob dilakukan pada variasi waktu tinggal limbah 1 dan 2 hari. Hasil pengolahan tahap anaerob, selanjutnya dialirkan ke bak pengolahan aerob dan dibiarkan pada variasi waktu tinggal limbah 1 dan 2 hari sambil diaerasi. Setelah waktu pendiaman tersebut, hasil pengolahan dianalisis kualitasnya. Pada tahap ini yang dianalisis adalah nilai COD dan BOD. Dari hasil perlakuan ini akan diperoleh waktu efektif terhadap waktu tinggal limbah pada masing-masing reaktor yang memberikan efisiensi perombakan paling besar. Waktu tinggal limbah efektif ini digunakan sebagai lawa waktu tinggal dalam mengolah limbah selanjutnya

\section{Uji Kualitas dan Toksisitas Hasil Pengolahan Limbah Tekstil}

Uji kualitas dan toksisitas hasil pengolahan ditujukan untuk menilai efektifitas dan efisiensi unit pengolahan yang diterapkan serta menilai dan kelayakan air limbah hasil pengolahan untuk dibuang ke lingkungan. Parameter yang diukur meliputi $\mathrm{pH}, \mathrm{COD}$ dan BOD, sulfida,
Amoniak bebas, Fenol dan minyak sesuai dengan persyaratan pada KepMen LH. No.51/MENLH/10/1995. Sedangkan analisis toksisitas dilakukan menggunakan ikan nila dengan waktu paparan selama 3 hari. Pelaksanaan uji toksisitas dilakukan dengan cara membuat seri konsentrasi limbah $100 \%$; $50 \%$; $25 \%$; $12,5 \%$ dan $6,25 \%$ sebanyak $1000 \mathrm{~mL}$. Masing-masing limbah ditambahkan 10 ekor ikan nila, selanjutnya diamati mortalitasnya setelah pemaparan 3 hari. Penilaian tingkat toksisitas akut berdasarkan klasifikasi nilai $\mathrm{EC}_{50}$ menurut Coleman dan Qureshi, (1985). Jika nilai $\mathrm{EC}_{50}$ dengan skala $\mathrm{EC}_{50}>100 \%$ = tidak toksik, $\mathrm{EC}_{50}>75-100 \%=$ toksisitas ringan, $E_{50}>50-75 \%=$ toksik, $E_{50}>25-50 \%$ toksisitas sedang dan $\mathrm{EC}_{50}<25 \%$ sangat toksik

\section{HASIL DAN PEMBAHASAN}

\section{Hasil Penelitian}

Hasil analisis COD dan BOD pada air limbah tekstil sebelum dan sesudah mengalami pengolahan pada reaktor semi anaerob-aerob disajikan pada Gambar 4.

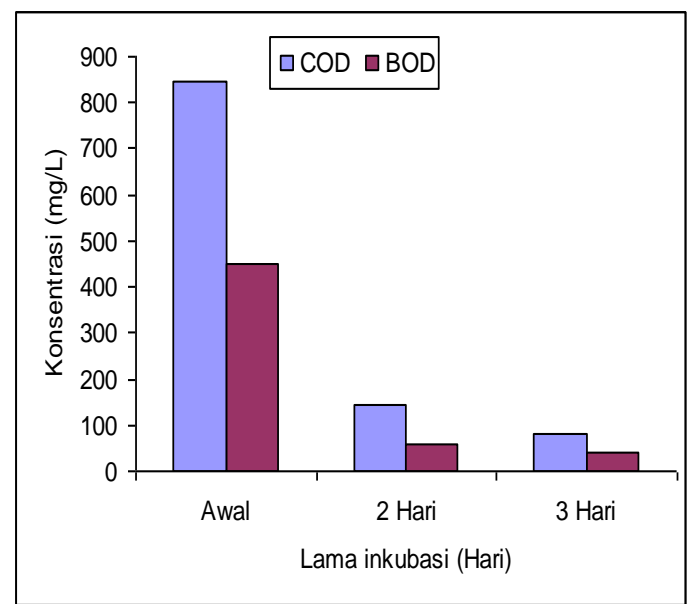

Gambar 4. Nilai COD dan BOD air limbah tekstil setelah mengalami perombakan pada variasi waktu inkubasi 
Gambar 4 memperlihatkan air limbah yang dihasilkan dari industri pencelupan tekstil mempunyai nilai COD dan BOD air sebesar $845 \mathrm{mg} / \mathrm{L}$ dan 450 $\mathrm{mg} / \mathrm{L}$. Nilai COD dan BOD dari limbah tersebut masih diatas baku mutu yang dipersyaratkan sesuai dengan KepMen LH No. 51/MENLH/10/1995 yaitu $150 \mathrm{mg} / \mathrm{L}$ untuk BOD dan $300 \mathrm{mg} / \mathrm{L}$ untuk COD. Namun, setelah mengalami perombakan dengan waktu tinggal limbah 1 hari pada fase semi anaerob-dan 1 hari pada fase aerob nilai COD dan BOD turun menjadi 145 $\mathrm{mg} / \mathrm{L}$ dan $60 \mathrm{mg} / \mathrm{L}$. Pengolahan air limbah dengan lama waktu 2 hari tahap semi anaerob dan 1 hari tahap aerob turun menjadi $42 \mathrm{mg} / \mathrm{L}$ dan $81 \mathrm{mg} / \mathrm{L}$. Hasil analisis menunjukkan bahwa pengolahan air limbah tekstil dengan waktu tinggal limbah 1 hari di fase semi anaerob dan 1 hari di fase aerob ditetapkan sebagai waktu efektif pengolahan.

Data kualitas air limbah tekstil sebelum dan setelah pengolahan selama 1 hari di semi anaerob dan 1 hari di aerob disajikan pada Tabel 1.

Tabel 1. Karakteristik air limbah tekstil sebelum dan setelah perombakan

\begin{tabular}{|l|l|c|c|c|c|}
\hline No & \multicolumn{1}{|c|}{ Parameter } & Satuan & $\begin{array}{c}\text { Sebelum } \\
\text { diolah }\end{array}$ & $\begin{array}{c}\text { Setelah } \\
\text { diolah }\end{array}$ & Baku mutu \\
\hline 1 & $\mathrm{pH}$ & - & 9,5 & 6,20 & $6-9$ \\
\hline 2 & Zat padat tersuspensi & $\mathrm{mg} / \mathrm{L}$ & 850 & 130 & 400 \\
\hline 3 & Sulfida( $\left.\mathrm{H}_{2} \mathrm{~S}\right)$ & $\mathrm{mg} / \mathrm{L}$ & 0,1 & $<0,01$ & 0,30 \\
\hline 4 & Amonia bebas $\left(\mathrm{NH}_{3}-\mathrm{N}\right)$ & $\mathrm{mg} / \mathrm{L}$ & 1,5 & 0,95 & 8,00
\end{tabular}

Standard baku mutu menurut KepMenLH No.51/MENLH/10/1995

Evaluasi efek toksik terhadap air limbah tekstil sebelum dan setelah mengalami perombakan dilakukan dengan menggunakan ikan nila. Persentase mortalitas ikan nila terhadap konsentrasi limbah setelah paparan 3 hari disajikan pada Gambar 5. 

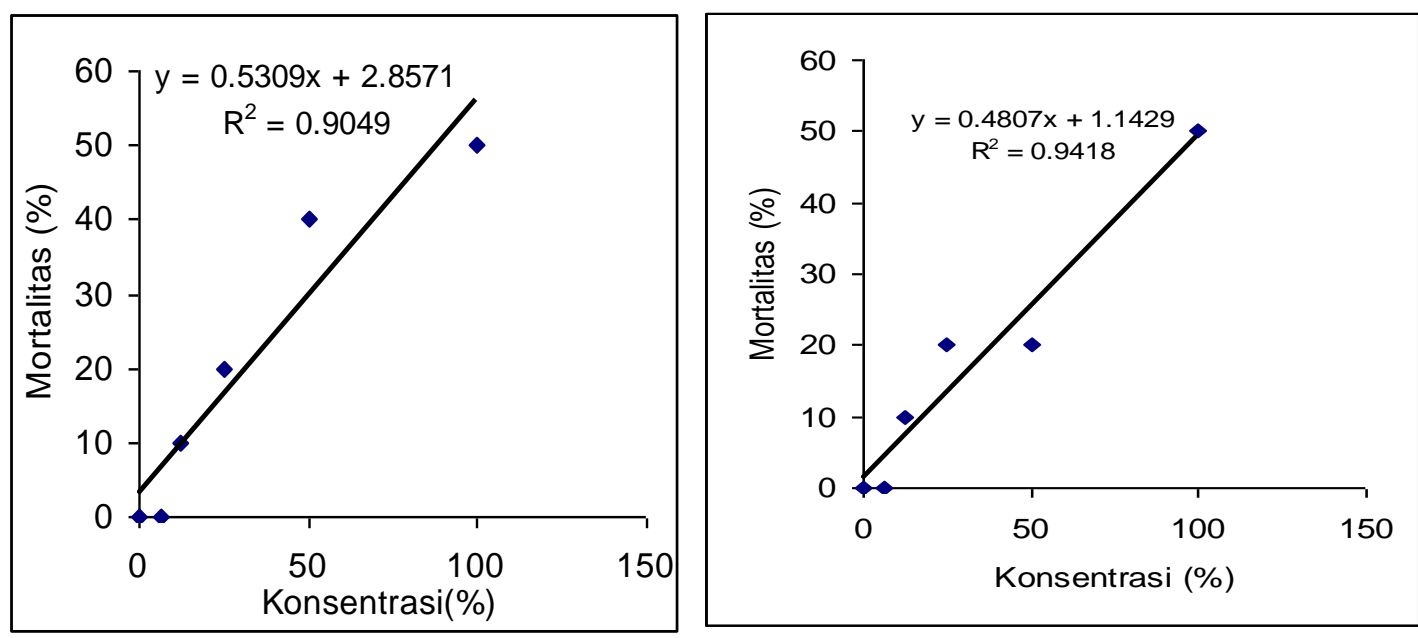

Gambar 5. Kurva persentase mortalitas ikan nila terhadap konsentrasi air limbah pada paparan 2 hari.

Gambar 5 diperoleh persamaan garis untuk limbah pencelupan tekstil sebelum dan setelah perombakan berturut-turut adalah $y=0,531 x+2,857$ dan $y=0,407+$ 1,1429. Dari persamaan garis tersebut diperoleh nilai $\mathrm{LC}_{50}$ untuk limbah sebelum dirombak sebesar $88,80 \%$. Sedangkan nilai $\mathrm{LC}_{50}$ untuk limbah setelah dirombak lebih besar dari 101,64\%.

Penilaian toksisitas akut berdasarkan klasifikasi nilai $\mathrm{EC}_{50}$ untuk limbah tekstil menurut Coleman dan Qureshi, (1985) adalah bila nilai $\mathrm{EC}_{50}>100 \%=$ tidak toksik, $\mathrm{EC}_{50}>75-100 \%=$ toksisitas ringan, $\mathrm{EC}_{50}$ $>50-75 \%=$ toksik, $E_{50}>25-50 \%$ toksisitas sedang dan $E_{50}<25 \%$ sangat toksik. Dengan demikian air limbah tekstil sebelum diolah berada dalam katagori toksik ringan $($ EC50 $=88,80 \%)$ sedangkan setelah mengalami perombakan dalam reaktor semi anaerob-aerob selama 2 hari inkubasi menjadi tidak toksik $\left(\mathrm{EC}_{50}=101,64 \%\right)$.

\section{PEMBAHASAN}

Batu vulkanik memiliki permukaan yang kasar dengan tingkat porositas besar sehingga sangat memenuhi memenuhi syarat untuk digunakan sebagai bahan pengamobil. Hasil analisis efektifitas penggunaan batu vulkanik sebagai bahan pengamobil bakteri yang dilakukan Sastrawidana, (2010) menunjukkan bahwa jumlah konsorsium bakteri yang terlekat pada batu vulkanik dalam reaktor semi anaerob dan reaktor aerob setelah digunakan merombak limbah secara berulang-ulang tetap stabil, yaitu masingmasing sebesar $20,51 \times 10^{9}$ dan $1,72 \times 10^{10}$ $\mathrm{cfu/gram}$ batu vulkanik. Ketersediaan koloni bakteri sangat menentukan efektivitas dan efisiensi perombakan. Menurut Cutright (2001), jumlah bakteri yang dianggap memadai digunakan untuk merombak limbah adalah sebesar $10^{3}-10^{8} \mathrm{cfu} / \mathrm{liter}$ limbah cair atau $10^{4}-10^{7} \mathrm{cfu} / \mathrm{gram}$ limbah padat. Hasil penelitian ini menunjukkan biofilm konsorsium bakteri pada batu 
vulkanik merah sudah terbentuk walaupun proses waktu tinggal pembentukannya dilakukan selama 10 hari. Hal ini ditunjukkan dengan kemampuannya menurunkan nilai COD dan BOD air limbah tekstil ketika digunakan dalam proses pengolahan air limbah tekstil.

Biofilm bakteri memiliki keunggulan dibandingkan dengan bakteri yang hidup secara bebas. Beberapa keunggulannya adalah menghasilkan kepadatan populasi sel yang lebih tinggi, lebih efisien terhadap penggunaan nutrisi dan lebih tahan terhadap perubahan kondisi lingkungan. Hal ini menghasilkan aktivitas biodegradasi yang lebih tinggi dibandingkan dengan pertumbuhan tersuspensi (Brault 1991). Kajian yang dilakukan oleh Sastrawidana, (2010) menunjukkan bahwa perombakan air limbah dengan menggunakan proses pertumbuhan terlekat menghasilkan efisiensi perombakan yang lebih tinggai dibandingkan dengan menggunakan sistem pertumbuhan tersuspensi.

Air limbah tekstil yang dihasilkan dari proses pencelupan tekstil di Industri pencelupan tekstil di Denpasar memiliki keasaman $(\mathrm{pH})$ basa yaitu 9,5. Tingginya $\mathrm{pH}$ air limbah tekstil ini disebabkan oleh pemakaian $\mathrm{NaOH}, \mathrm{Na}_{2} \mathrm{CO}_{3}$ atau detergen dalam proses pencelupan tekstil. Bakteri yang digunakan untuk proses pengolahan limbah dalam penelitian ini berkembang dan beraktivitas optimum pada kondisi netral atau sedikit basa $(\mathrm{pH}$ 6-8). Untuk itu, sebelum pengolahan, air limbah dikondisikan pada $\mathrm{pH}$ 6-8 dengan cara menambahkan larutan asam klorida. Zat warna tekstil yang digunakan oleh pelaku tekstil dominan tergolong zat warna azo. Dengan demikian, proses perombakannya merupakan reaksi redok. Bakteri menggunakan kosubstrat yaitu glukosa untuk membantu proses perombakan. Perombakan glukosa dalam sel bakteri menghasilkan koenzim NADH yang selanjutnya bereaksi redoks dengan zat warna azo. Zat warna azo mengalami reaksi reduksi membentuk senyawa amina aromatik. Proses redoks berlangsung lebih efektif pada kondisi ketersediaan oksigen sangat sedikit bahkan kondisi tanpa oksigen. Dilain pihak, perombakan secara anaerob terhadap zat warna azo menghasilkan amina aromatik yang umumnya lebih potensial toksik dibandingkan dengan zat warna azo itu sendiri. Untuk itu, pengolahan air limbah tekstil dengan menggunakan sistem kombinasi semi anaerob-aerob menjadi tepat untuk digunakan. Hasil pengolahan dengan sistem kombinasi semi anaeroaerob menggunakan i konsorsium bakteri yang terlekat pada batu vulkanik merah dengan waktu tinggal limbah dalam reaktor 2 hari, yaitu 1 hari pada masing-masing reaktor menghasilkan air limbah dengan kondisi pH yang netral yaitu sebesar 6,2. Persyaratan kondisi $\mathrm{pH}$ air limbah berdasarkan KepMen LH No.51/MENLH/10/1995 yang dianggap aman adalah 6-9,dengan demikian sudah memenuhi persyaratan baku mutu limbah industi untuk dibuang ke lingkungan.

Padatan tersuspensi total atau total suspended solid (TSS) dari air limbah tekstil sebelum diolah sebesar $850 \mathrm{mg} / \mathrm{L}$. TSS yang tinggi pada air limbah berdampak negatif terhadap perairan karena dapat mengurangi penetrasi sinar matahari yang masuk ke badan air sehingga menyebabkan timbulnya aktivitas mikrob anaerob yang tinggi dengan menghasilkan produk akhir seperti amonia, asam sulfida yang bau yang tak sedap. Setelah diolah dengan waktu tinggal limbah 2 hari dalam reaktor anaerobaerob mampu menurunkan nilai TSS menjadi $130 \mathrm{mg} / \mathrm{L}$ atau efisiensi penurunan TSS sebesar $85 \%$ Nilai TSS pada air limbah hasil pengolahan selama 2 hari telah memenuhi syarat, karena ambang batas TSS dipersyaratkan dalam KepMen LH No. 51/MENLH/10/1995 yaitu sebesar 400 mg/L. 
Air limbah tekstil yang digunakan dalam penelitian ini mempunyai nilai $\mathrm{BOD}_{5}$ dan COD masing-masing sebesar $450 \mathrm{mg} / \mathrm{L}$ dan $845 \mathrm{mg} / \mathrm{L}$. Nilai $\mathrm{BOD}_{5}$ dan COD menggambarkan kandungan bahan organik pada air limbah. Penyusun utama bahan organik biasanya berupa polisakarida (karbohidrat), polipeptida (protein) dan lemak. Selain jenis bahan organik tersebut, limbah organik juga mengandung bahan organik sintetik seperti pestisida dan surfaktan. Tingginya bahan organik pada air limbah tekstil dihasilkan dari pemakaian bahan-bahan kimia dalam proses produksi tekstil. Pada umumnya enzim, detergen, water glass dan zat warna sintetik sangat intensif digunakan. Setelah dilakukan pengolahan dengan kombinasi anaerobaerob dengan waktu tinggal 2 hari, nilai $\mathrm{BOD}_{5}$ turun menjadi $42,48 \mathrm{mg} / \mathrm{L}$ atau efisiensi penurunan $\mathrm{BOD}_{5}$ sebesar $90,56 \%$. Nilai COD turun menjadi $81,12 \mathrm{mg} / \mathrm{L}$ atau efisiensi penurunan COD sebesar $90,40 \%$. Hal ini menunjukkan bahwa penguraian bahan-bahan organik yang terdapat pada limbah tekstil menggunakan sistem kombinasi semianaerob-aerob berlangsung efisien. Nilai $\mathrm{BOD}_{5}$ dan $\mathrm{COD}$ hasil pengolahan ini sudah berada dibawah baku mutu air yang dipersyaratkan dalam KepMen LH No. 51/MENLH/10/1995.

Limbah tekstil setelah diolah dalam reaktor kombinasi anaerob-aerob selama 2 hari menggunakan konsorsium bakteri terlekat pada batu vulkanik merah menghasilkan nilai $\mathrm{EC}_{50}$ sebesar 101,64\% Temuan ini, menunjukkan bahwa pengolahan air limbah tekstil dengan teknologi ini mampu menghasilkan air limbah dalam katagori tidak tosksik. Hasil penelitian ini sejalan dengan hasil kajiankajian tentang toksisitas perombakan zat warna azo yang telah dilakukan oleh peneliti sebelumnya. Melgoza et al.(2004), melakukan kajian toksisitas hasil perombakan zat warna azo disperse blue pada kondisi anaerob-aerob. Hasil kajiannya adalah zat warna disperse blue termasuk katagori tidak toksik tetapi setelah mengalami fase perombakan anaerob toksisitasnya meningkat menjadi 14,4 satuan toksisitas. Meningkatnya toksisitas hasil perombakan anaerob disebabkan oleh terbentuknya produk amina aromatik berupa senyawa amina 2-bromo 4,6 dinitroanilin (BDNA) dan N,N disubstitusi 1,4-diaminbenzen (NNDB) pada perombakan disperse blue. Akan tetapi, kedua senyawa amina aromatik tersebut mengalami perombakan lebih lanjut pada fase aerob sehingga toksisitasnya menjadi menurun. Frijters et al. (2006) dalam kajiannya melaporkan bahwa toksisitas hasil perombakan limbah tekstil pada fase anaerob lebih besar dibandingkan limbah aslinya. Toksisitas limbah menjadi menurun setelah memasuki fase pengolahan aerob. Shin et al. (2002), melaporkan zat warna azo amaranth sebelum dan sesudah dirombak menggunakan jamur Trametes versicolor mempunyai nilai $\mathrm{EC}_{50}$ ebih besar dari $100 \%$ terhadap Vibrio fischeri selama paparan 48 jam. Hal ini berarti zat warna tersebut sebelum dan sesudah dirombak berada dalam katagori tidak toksik.

\section{SIMPULAN DAN SARAN Simpulan}

Pengolahan air limbah tekstil menggunakan sistem kombinasi semi anaerob-aerob dalam reaktor berisikan bakteri teramobil pada batu vulkanik merah berlangsung efektif dan efisien. Konsorsium bakteri yang digunakan pada reaktor semi anaerob terdiri dari Aeromonas sp. Pseudomonas sp. Flavobacterium sp. dan Enterobacter sp. sedangkan pada reaktor aerob terdiri dari Vibrio sp. Plesiomonas sp dan Enterobacter sp. Perombakan air limbah pencelupan tekstil dengan waktu tinggal limbah 2 hari yaitu 1 hari tahap pengolahan semi anaerob dan 1 hari tahap pengolahan aerob menghasilkan efisiensi perombakan 
TSS, BOD dan COD secara berturut-turut sebesar $84,7 \% ; 80,56 \%$ dan $90,40 \%$.

Beberapa nilai parameter kualitas air limbah tekstil sebelum dilakukan pengolahan berada di atas standar baku mutu yang dipersyaratkan dalam KepMen LH No. 51/MENLH/10/1995. Namun, setelah dirombak dengan waktu tinggal limbah 2 hari pada reaktor semianaerob-aerob berisikan biofilm konsorsium bakteri yang terlekat pada batu vulkanik merah, semua parameter yang diukur berada di bawah standar baku mutu yang berarti sudah memenuhi syarat untuk dibuang ke lingkungan.

Uji toksisitas air limbah tekstil menggunakan ikan nila dengan waktu paparan 3 hari menunjukkan bahwa air limbah tekstil sebelum diolah berkatagori toksik ringan dengan nilai $\mathrm{EC}_{50}$ adalah $88,80 \%$ sedangkan setelah diolah dalam reaktor biofilm konsorsium bakteri sistem anaerob-aerob dengan waktu tinggal limbah dalam reaktor 2 hari menjadi katagori tidak toksik yang ditunjukkan oleh nilai $E_{50}$ sebesar 101,64\%. Dengan demikian, pengolahan limbah tektil dengan teknologi biofilm sistem kombinasi semi anaerobaerob berisikan konsorsium bakteri terlekat pada batu vulkanik merah menghasilkan air limbah yang dengan nilai parameter yang diamati berada di bawah standar baku mutu yang dipersyaratkan pada KepMen LH No. 51/MENLH/10/1995 sehingga sudah memenuhi syarat untuk bisa dibuang ke lingkungan.

\section{Saran}

Teknologi biofilm konsorsium bakteri yang terlekat pada batu vulkanik merah pada reaktor semianaerob-aerob mampu secara efektif untuk mengolah limbah tekstil. Namun masih perlu dilakukan penelitian kembali terhadap rancangan reaktor yang lebih efektif dalam menangani air limbah tekstil dalam jumlah yang lebih besar.

\section{DAFTAR PUSTAKA}

Blackburn, R.S.\& Burkinshaw, S.M. 2002. A Greener to cotton dyeing with excellent wash fastness. Green Chemistry. 4: 4752.

Castilla, C.M., Toledo,I.B., Garcia,M.A.C., Utrilla, J.R. 2003. Influence of support surface properties on activity of bacteria immobilized on activated carbons for water denitrification. Carbon. 41: 17431749.

Chen, K., Huang, W.,Wu, J.\& Houng, J. 1999. Microbial decolorization of azo dyes by Proteus mirabilis. Journal of Microbiology and Biotechnology. 23: 686690

Coleman. R.N., \& Qureshi, A.A. 1985. Microtox and Spirillum polutants tes for assessing toxicity of environmentals samples. Bull Environ Contam Toxicol. 35:443-451.

Cutright, T.J. 2001. Biotechnology: Principles and Advances in Waste Control. Departement of Civil Engineering. University of Akron.

Melgoza, R.M., Cruz,A.,\& Bultron, G. 2004. Anaerobic-Aerobic treatment of colorants present in textile effluents. Water Science Technology. 50: 149155

Pandey, A., Singh,P.\& Lyengar, L. 2007. Bacterial decolorization and degradation of azo dyes. International Biodeteoration and Biodegradation. 59: 73-84.

Prakash, B., Veeregowda, B.M. \& Krishnappa, G. 2003. Biofilms : $A$ survival strategy of bacteria. Current Sci. 85(9): 1299-1307.

Qureshi, N., Annous,B.A., Ezeji,T.C., Karcher, P., \& Maddox, I.S. 2005. Biofilm reactors for industrial bioconcersion processes: employing 
potential of enhanced reaction rates. Microbial Cell Factories 4: 1-24.

Sastrawidana,. 2009. Perombakan zat warna reaktif azo menggunakan konsorsium bakteri dari lumpur limbah tekstil. Jurnal Wahana Matematika dan Sains.UniversitasPendidikan Ganesha. 6(12):75-86

Sastrawidana. 2010. Analisis Efisiensi Perombakan Limbah Tekstil Buatan Pada Reaktor Kombinasi AnaerobAerob menggunakan Proses pertumbuhan Terlekat dan Sel Bebas. Jurnal Penelitian Sain dan Humaniora, Lembaga Penelitian Universitas Pendidikan Ganesha. 4(3): 229-239
Shin, M., Nguyen,T \& Ramsay, J. 2002. Evaluation on support materials for the surface immobilization and decoloration of amaranth by Trametes versicolor. Applied microbiology and biotehcnology. 60:218-223.

Wuhrmann, K., Mechsner, K.\& Kappeler, T. 1980. Investigations on rate determining factors in the microbial reduction of azo dyes. Applied Microbiology and Biotechnology. 9:325328.

Yoo, E.S. 2000. Biological and chemical mechanisms of reductive decolorization of azo dyes [Dissertation] Genehmigte Berlin. 